\title{
Pelatihan Aplikasi Geogebra Android bagi Guru MGMP Matematika SMA Kabupaten Barito Kuala
}

\author{
Ahmad Lazwardi ${ }^{1}$, Rahmatya Nurmeidina $^{2^{*}}$, Akhmad Ilmi ${ }^{3}$, Siska Monica ${ }^{4}$ \\ 1-4 Universitas Muhammadiyah Banjarmasin \\ 1'lazwardiahmad@gmail.com; ${ }^{2 *}$ rahmatya.dina@gmail.com; ${ }^{3}$ akhmadilmio12@gmail.com; \\ ${ }^{4}$ siskamonica26@gmail.com;
}

\begin{abstract}
Abstrak
Dalam pembelajaran matematika, siswa memerlukan suatu media berbasis teknologi yang dapat mewakili intuisinya dalam memahami suatu konsep matematis. Tujuan dari pengabdian ini adalah untuk menyosialisasikan Geogebra Android sebagai aplikasi open source untuk memvisualisasikan grafik fungsi dengan sangat akurat dan simpel kepada MGMP Matematika SMA Kabupaten Barito Kuala. Metode yang digunakan dalam kegiatan pengabdian kepada masyarakat ini adalah metode pelatihan. Hasil dari pelatihan ini adalah peserta pelatihan dapat menggunakan aplikasi Geogebra dalam pembelajaran matematika. Dengan penggunaan aplikasi dalam pembelajaran dapat meningkatkan minat dan pemahaman siswa.
\end{abstract}

Kata Kunci: Geogebra, Android, grafik

\section{Pendahuluan}

Kemampuan abstraksi dalam matematika merupakan komponen utama yang wajib untuk dimiliki oleh setiap siswa pada pembelajaran matematika. Tanpa kemampuan abstraksi ini, siswa akan sangat kesulitan dalam menentukan pola, arah, tujuan serta akibat dari keberadaan suatu objek matematika. Akibatnya, siswa akan merasa sengat kesulitan dalam belajar dan menjawab soal-soal matematika. Kemampuan berpikir matematis harus dimiliki oleh setiap siswa. Memang, kemampuan berpikir matematis merupakan kunci utama dalam belajar matematika. Dengan kemampuan ini, siswa dapat memecahkan masalah yang diberikan (Nurhikmayati, 2017).

Teknologi telah menjadi salah satu sumber belajar yang digunakan di zaman sekarang ini. Menurut eMarketer, pengguna smartphone di Indonesia pada akhir 2015 sekitar 55 juta, 2016 65,2 juta dan 2017 diperkirakan 7,9 juta. Sebagian besar pengguna Android adalah pelajar. Dengan demikian, guru dapat memanfaatkan Android dalam proses pembelajaran, misalnya dengan menggunakan software matematika di dalam kelas. Diharapkan dengan kemajuan teknologi akan memudahkan siswa dalam memahami matematika (Budiman \& Ramdhani 2017). Kemajuan teknologi dintegrasikan dalam pembelajaran melalui media pembelajaran. Pembelajaran yang terintegrasi teknologi dapat membuat pembelajaran lebih bermakna karena penggunaan media mempunyai fungsi untuk mewujudkan situasi pembelajaran yang aktif, efektif dan menyenangkan (Firdayanti, 2020). Pembelajaran matematika hendaknya menggunakan strategi ataupun media pembelajaran yang bervariasi dan dapat menarik minat belajar siswa dan membantu siswa memahami konsep secara mendalam serta mampu mengembangkan 
kecakapan matematis (Nurdin et al., 2019). Salah satu media pembelajaran yang terintegrasi teknologi adalah Geogebra.

GeoGebra adalah program komputer (software) untuk matematika, khusus untuk studi geometri dan aljabar. GeoGebra adalah aplikasi perangkat lunak online gratis untuk mempelajari geometri, aljabar, dan analisis. Kelebihan Geogebra adalah dapat memvisualisasikan material geometris. Dengan keterampilan visualisasi yang komprehensif, program ini dirancang untuk meningkatkan motivasi siswa (Kusuma and Utami 2017). Selain meningkatkan motivasi belajar, pembelajaran menggunakan aljabar geografis juga dapat meningkatkan pemecahan masalah dan prestasi akademik siswa (Wigati 2019). Penelitian sebelumnya menunjukkan bahwa penerapan aljabar geografis sangat efektif dalam meningkatkan kualitas pembelajaran matematika di sekolah menengah. Penelitian Budiman \& Ramdhani (2017) menunjukkan bahwa pengembangan bahan ajar berbasis GeoGebra versi Android dinilai valid, praktis, dan berpotensi mempengaruhi prestasi dan tingkat aktivitas siswa. Sementara itu, Idris (2015) melakukan penelitian tindakan kelas yang bertujuan untuk meningkatkan hasil belajar Program Linier melalui strategi pembelajaran berbasis pertanyaan dan penerapan GeoGebra pada siswa di kelas XII IPA1 SMA Negeri 1 Tompobulu. Dalam penelitian Widyaningrum dan Murwanintyas (2012) juga menunjukkan fakta bahwa anak-anak di SMA Negeri 2 Yogyakarta yang menggunakan media Geogebra juga memiliki hasil belajar yang lebih tinggi daripada anak yang tidak menggunakan Geogebra. Penelitian ini juga memberikan hasil yang baik. Penelitian Supriadi (2015) menunjukkan bahwa pembelajaran geometri berbasis GeoGebra dalam proses pembelajaran terbukti secara signifikan meningkatkan kemampuan komunikasi matematis siswa, selain itu siswa juga menunjukkan sikap kritis dan kreativitas dalam pembelajaran.

Berdasarkan penjelasan di atas, kami telah memilih untuk membagikan penggunaan GeoGebra untuk platform Android dengan guru Matematika MGMP SMA Kab. Batola. Tujuan dari pelatihan ini adalah sebagai bentuk pengabdian para guru pendidikan matematika di Universitas Muhammadiyah Banjarmasin untuk memberikan kontribusi ilmiah kepada masyarakat. Setelah kegiatan pelatihan ini direncanakan untuk menjalin kerjasama antara universitas dan sekolah. Manfaat diselenggarakannya kegiatan ini antara lain: 1) Guru dapat lebih mudah menyiapkan materi pembelajaran matematika secara online. 2) Siswa lebih memahami matematika.

\section{Metode Pelaksanaan}

Metode yang digunakan dalam kegiatan pengabdian kepada masyarakat ini adalah metode pelatihan. Pelatihan dilakukan melalui tahap-tahap berikut: a) Diadakan presentasi berupa pengenalan aplikasi Geogebra untuk Android, dari cara instalnya, fitur-fiturnya dan beberapa formulasi penting yang sering digunakan dalam pencitraan grafik permukaan. b) Mahasiswa melakukan demonstrasi penggunaan Geogebra untuk Android. c) Para peserta mulai mencoba menggunakan Geogebra untuk Android dalam sesi tanya jawab dan diskusi. Peserta pelatihan adalah 41 orang guru peserta MGMP Matematika SMA Kabupaten Barito Kuala. 


\section{Hasil dan Pembahasan}

Kegiatan pengabdian ini dilakukan secara online dengan seluruh guru MGMP Matematika SMA Kab. Batola pada 27 April 2021. Para guru mengikuti kegiatan ini dengan antusias dan penuh kebahagiaan. Pelatihan ini dilakukan secara online menggunakan aplikasi Google Meet.

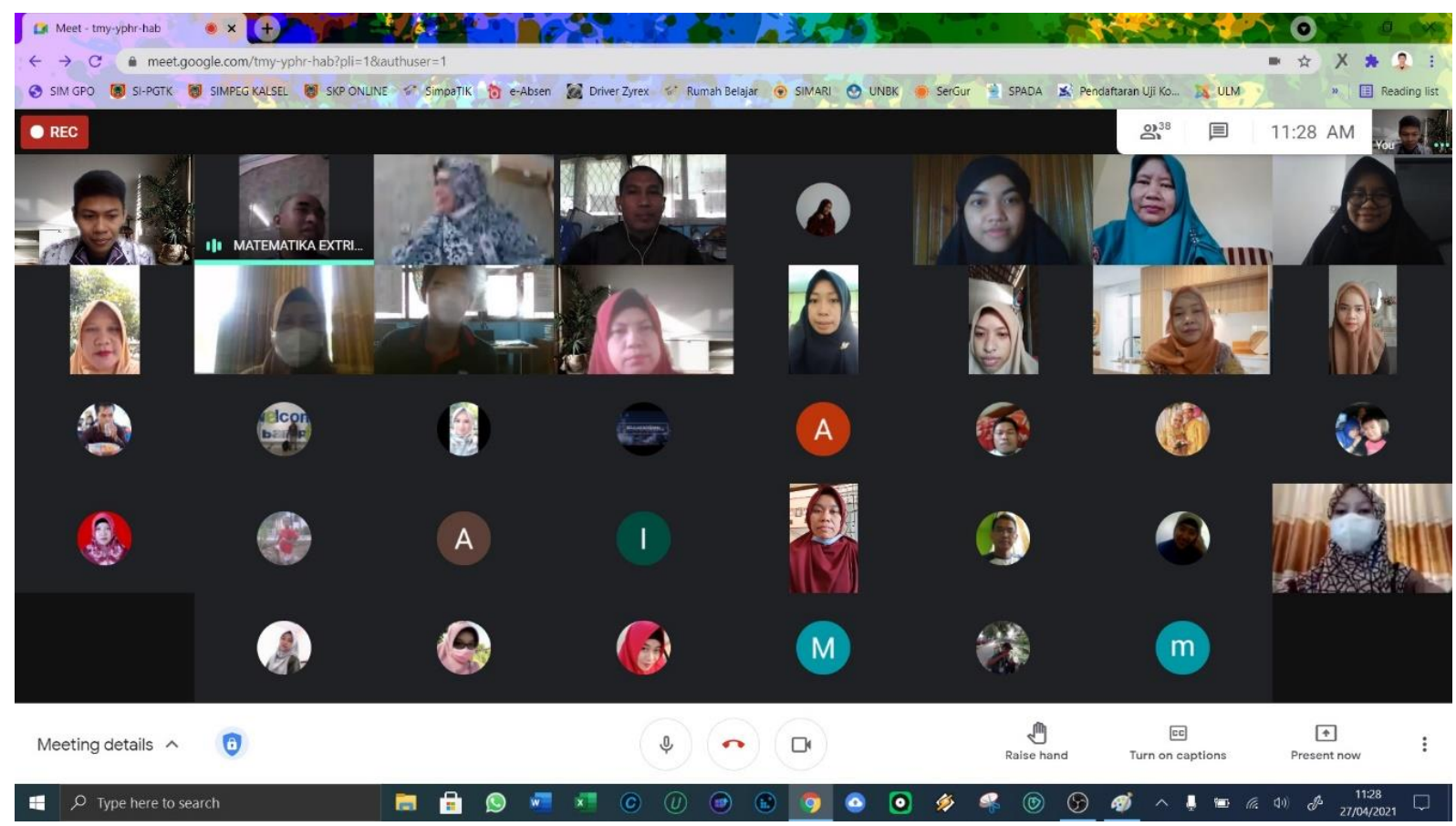

Gambar 1. Pelatihan Geogebra untuk Android

Adapun kegiatan dilakukan dengan tahapan sebagai berikut. Pertama-tama dijelaskan tentang apa itu aplikasi Geogebra untuk platform Android dan perbedaannya dengan Geogebra untuk Windows. Kelebihan serta kekurangannya. Ada beberapa kelebihan dari Geogebra 3D adalah mempunyai tampilan yang lebih sederhana tetapi tetap tidak menghilangkan fitur fitur penting seperti kemampuan memvisualisasikan grafik fungsi dua peubah, mendeteksi kekontinuan fungsi, menentukan bentuk visual dari irisan maupun gabungan dari dua atau lebih daerah 3 dimensi. Dalam pelaksanaan pelatihan ini, perangkat yang digunakan sengaja menggunakan handphone android agar proses demonstrasi berjalan dengan lebih realistis.

Pada tahap selanjutnya mulai dijelaskan tentang fitur-fitur Geogebra 3D khususnya yang berkaitan dengan visualisasi objek geometris pada ruang 3D. Di tahap ini dijelaskan tentang cara menjelaskan system koordinat 3 dimensi. Posisi titik koordinat, sumbu absis, ordinat dan aplikat. Kemudian dijelaskan pula cara menulis persamaan matematika yang ingin divisualisasikan berdasarkan syntax yang ada pada Geogebra 3D. Penjelasan dibantu juga oleh Akhmad Ilmi mahasiswa Prodi Pendidikan Matematika UM Banjarmasin angkatan 2018 dalam memperagakan penggunaan aplikasi. 


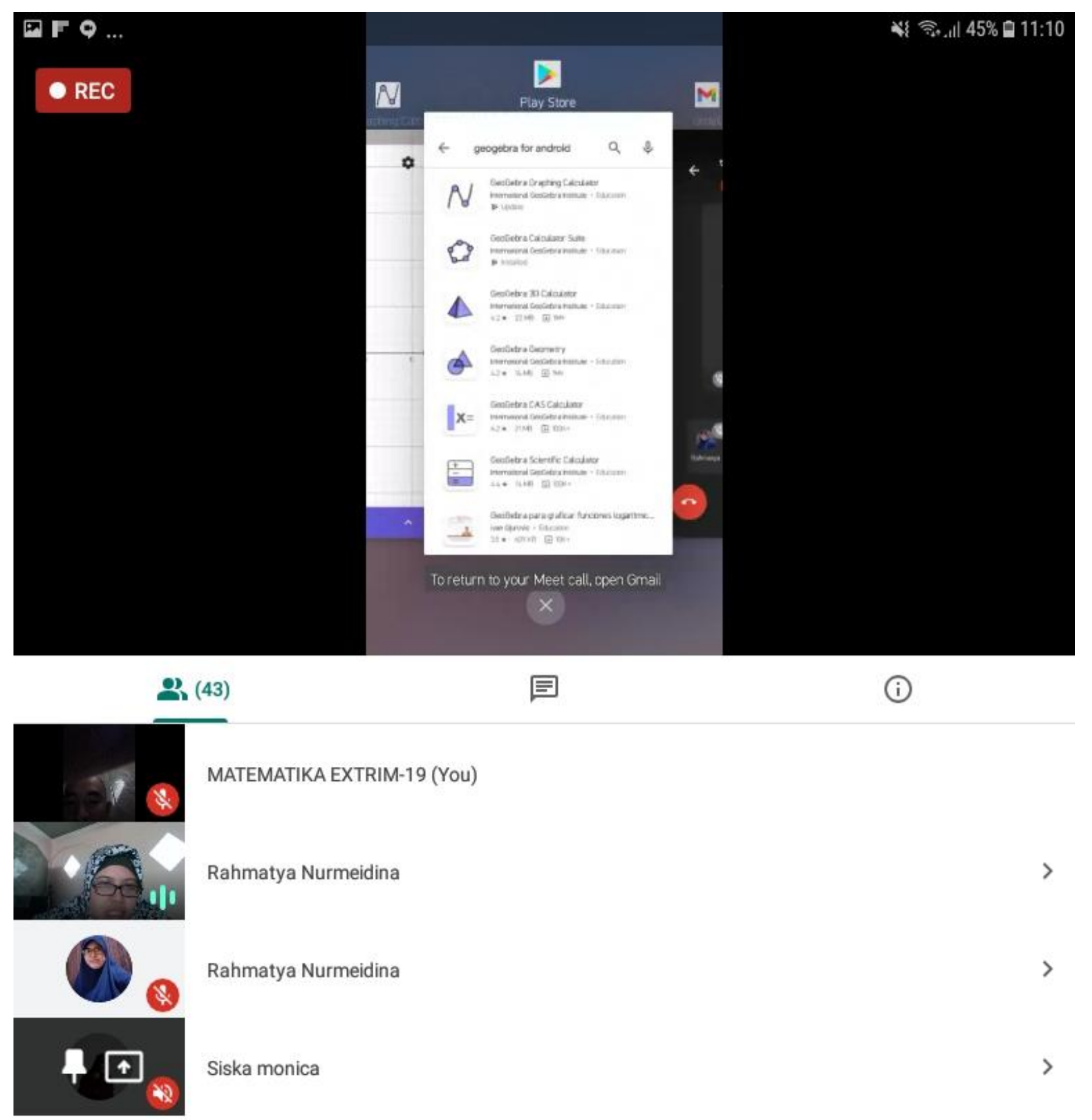

Gambar 2. Pengenalan tampilan awal Geogebra untuk Android

Selanjutnya dijelaskan GeoGebra untuk bidang 2 dimensi. Di tahap ini dijelaskan tentang membuat grafik fungsi yang hasilnya jauh lebih detil daripada menggambar grafik secara manual. Sebagai contoh yaitu dalam menjelaskan grafik fungsi trigonometri. Penjelasan dibantu juga oleh Siska Monica, mahasiswi Prodi Pendidikan Matematika UM Banjarmasin angkatan 2018 dalam memperagakan penggunaan aplikasi untuk mencari solusi Sistem Persamaan Linier Dua Variabel. Selain bidang 2 dimensi, juga didemonstrasikan penggunaan GeoGebra pada bidang 3 dimensi. Selanjutnya, juga dijelaskan bagaimana cara menyimpan hasil penggunaan aplikasi. Hasil gambar dengan geogebra dapat di simpan dalam bentuk gambar jpeg, png atau simpan dokumen sebagai file yang hanya dibuka di aplikasi geogebra. Selain itu kita juga dapat mengirimkannya langsung dari aplikasi geogebra ke nomor whatsapp teman atau email. 

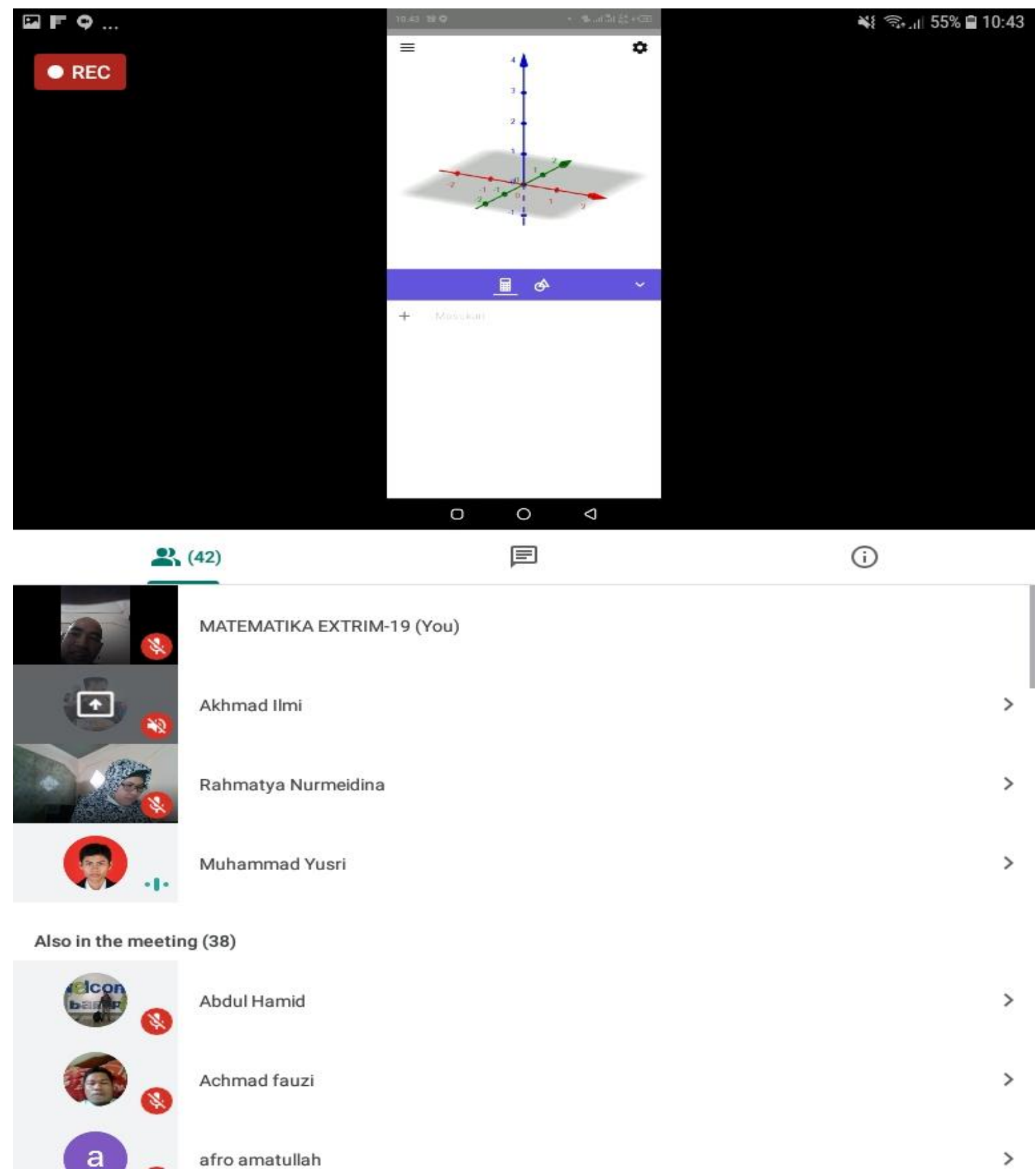

(i)

回

Gambar 3. Tahap demonstrasi penggunaan Geogebra untuk Android

Setelah mengikuti pelatihan ini diharapkan dosen dapat menerapkan aplikasi geogebra dalam pembelajaran matematika di kelas. Dengan menggunakan geogebra dapat meningkatkan pemahaman matematis siswa, sesuai dengan penelitian Yanti et al. (2019) terdapat perbedaan signifikan peningkatan pemahaman konsep matematis siswa yang menerapkan pendekatan saintifik berbantuan Geogebra dan yang menggunakan pembelajaran biasa. Selain meningkatkan pemahaman konsep matematis geogebra juga dapat meningkatkan motivasi belajar siswa (Wigati, 2019) dan minat belajar siswa (Wondo, Mei, \& Seto, 2020). 


\section{Kesimpulan}

Hasil dari pelatihan Geogebra Android yang dihadiri oleh guru-guru MGMP Matematika SMA Kabupaten Batola ini memberikan pencerahan bagi peserta pelatihan dalam merancang dan merencanakan pembelajaran matematika secara daring, sehingga kualitas pembelajaran tetap terjaga. Peserta yang mengikuti kegiatan pengabdian ini sangat antusias. Diharapkan setelah mengikuti pengabdian ini, guru-guru MGMP Matematika SMA Kab.Batola dapat menerapkan pembelajaran menggunakan aplikasi geogebra ketika pembelajaran matematika baik secara daring maupun luring. Dengan demikian siswa dapat lebih termotivasi dan beminat dalam mata pelajaran matematika.

\section{Ucapan Terimakasih}

Ucapan terimakasih disampaikan kepada: 1) Dekan FKIP Universitas Muhammadiyah Banjarmasin selaku institusi penyelenggara pengabdian ini yang telah memberikan dukungan secara maksimal, 2) Ketua MGMP Batola selaku mitra kerja dalam pengabdian ini yang sudah bersedia menyediakan waktu, tempat dan kesempatan pelaksanaan kegiatan ini sehingga pengabdian ini berhasil dilaksanakan dengan optimal, 3) Mahasiswa yang telah membantu dalam pelaksanaan kegiatan pengabdian ini sehingga manfaat kegiatan pengabdian ini menjadi lebih mudah diterima oleh para peserta.

\section{Referensi}

Budiman, H., \& Ramdhani, s. (2017). Pengembangan Bahan Ajar Matematika SMA Berbasis Geogebra Versi Android. Jurnal Science Tech, 3(2), 75-80.

Firdayanti, L. (2020). Peningkatan Motivasi Belajar Siswa Melalui Discovery Learning Dengan GEOGEBRA Pada Materi Transformasi. AKSIOMA : Jurnal Program Studi Pendidikan Matematika, 9(3), 833-41.

Idris, S. (2015). Peningkatan Hasil Belajar Program Linear Melalui Strategi Pembelajaran Inkuiri dan Geogebra Siswa Kelas XII Ipa1 SMA N 1 Tompobulu. Indonesian Digital Journal of Mathematics and Education, 2(3), 144-53.

Kusuma, A., \& Utami, A. (2017). Penggunaan Program Geogebra dan Casyopee dalam Pembelajaran Geometri Ditinjau dari Motivasi Belajar Siswa. Jurnal Mercumatika : Jurnal Penelitian Matematika dan Pendidikan Matematika, 1(2), 119-131. https://doi.org/10.26486/mercumatika.v1i2.259

Nurdin, E., Ma’aruf, A., Amir, Z., Risnawati, R., Noviarni, N., \& Azmi, M. P. (2019). Pemanfaatan Video Pembelajaran Berbasis Geogebra Untuk Meningkatkan Kemampuan Pemahaman Konsep Matematis Siswa SMK. Jurnal Riset Pendidikan Matematika, 6(1), 87-98. https://doi.org/10.21831/jrpm.v6i1.18421

Nurhikmayati, I. (2017). Kesulitan Berpikir Abstrak Matematika Siswa Dalam Pembelajaran Problem Posing Berkelompok. KALAMATIKA Jurnal Pendidikan Matematika, 2(2), 159. https://doi.org/10.22236/kalamatika.vol2no2.2017pp159-176

Supriadi, N. (2015). Pembelajaran Geometri Berbasis Geogebra sebagai Upaya Meningkatkan Kemampuan Komunikasi Matematis Siswa Madrasah Tsanawiyah (MTs). Al-Jabar : Jurnal Pendidikan Matematika, 6(2), 99-110. https://doi.org/10.24042/ajpm.v6i2.20 
Widyaningrum, Y. T., \& Murwanintyas, C. E. (2012). Pengaruh Media Pembelajaran Geogebra Terhadap Motivasi Dan Hasil Belajar Siswa Pada Materi Grafik Fungsi Kuadrat Di Kelas X SMA Negeri 2 Yogyakarta Tahun Pelajaran 2012/2013. Seminar Nasional Matematika Dan Pendidikan Matematika FMIPA UNY Yogyakarta, 10 November 2012 (103):978-80.

Wigati, S. (2019). Penerapan Geogebra Handphone Android Untuk Meningkatkan Kemampuan Pemecahan Masalah, Keaktifan, Dan Motivasi Belajar Siswa. Jurnal Inovasi Pembelajaran Karakter (JIPK), 4(4), 1-7.

Wondo, M. T. S., Mei, M. F., \& Seto, S. B. (2020). Penggunaan Media Geogebra Dalam Pembelajaran Geometri Ruang Untuk Meningkatkan Minat Dan Hasil Belajar Mahasiswa. Jurnal Pendidikan Matematika, 11(2), 163. https://doi.org/10.36709/jpm.v11i2.12049

Yanti, R., Laswadi, L., Ningsih, F., Putra, A., \& Ulandari, N. (2019). Penerapan Pendekatan Saintifik Berbantuan Geogebra Dalam Upaya Meningkatkan Pemahaman Konsep Matematis Siswa. AKSIOMA : Jurnal Matematika Dan Pendidikan Matematika, 10(2), 180-94. https://doi.org/10.26877/aks.v10i2.4399 